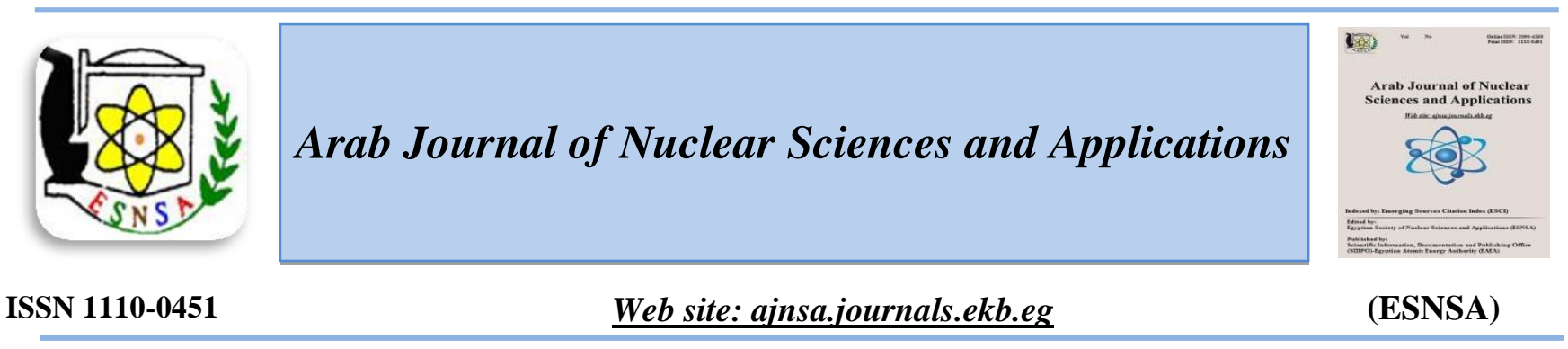

\title{
Purification and Studying Some Characters of Laccase Enzyme from Irradiated Pleurotus Ostreatus ATCC 56270
}

\author{
Ola E.A. Al-Hagar ${ }^{1}$, K.S. Attia ${ }^{2}$, A.F.A El-Aziz ${ }^{3}$, E.A. Marzook $^{2}$, Hoda A. Mansour ${ }^{2}$ \\ ${ }^{1}$ Plant Research Department, ${ }^{2}$ Biological Applications Division, Nuclear Research Center, Atomic Energy Authority, \\ Cairo, Egypt \\ ${ }^{3}$ Department of Chemistry, Faculty of Science, Mansura University, Mansura, Egypt
}

\begin{abstract}
Received 11 ${ }^{\text {th }}$ May 2018 Purification of laccase enzyme by anion exchange chromatography using DEAE sepharose and Accepted $19^{\text {th }}$ Feb. 2019 sephacryl HR are successful in purifying laccase. SDS- PAGE is the determined of laccase molecular weight which is $75 \mathrm{KDa}$. The optimum $\mathrm{pH}$ for activity was 5 and for stability was 6.5-7.5. The optimum temperature for activity was $35^{\circ} \mathrm{C}$ and stability of the enzyme was stable up to $55^{\circ} \mathrm{C}$, the enzyme retained $100 \%$ of its activity after 20 minutes incubation, $85 \%$ of its activity after $1 \mathrm{~h}$ incubation at the same temperature. The activation energy $\left(E_{\text {act }}\right)$ of the purified laccase between $20^{\circ} \mathrm{C}$ and $45^{\circ} \mathrm{C}$ at its optimum pH was $16.3 \mathrm{k} \mathrm{Jmol}^{-1}$. The apparent $K_{m}$ value of the enzyme for ABTS was estimated to be $1.4 \mathrm{mM}$ under standard assay conditions, $k_{\text {cat }}$ value of ABTS was calculated to be $3450 \mathrm{~min}^{-1}$ and $V_{\text {max }}$ is the maximum initial rate in the Michaelis-Menten equation $\left(1.2 \mu \mathrm{mol} \mathrm{L}^{-1} \mathrm{~min}^{-1}\right)$. Microencapsulation of laccase exhibited that free laccase $(35 \mathrm{U} / \mathrm{ml})$ has higher activity than encapsulated laccase $(24.3 \mathrm{U} / \mathrm{ml})$.
\end{abstract}

Keywords: Laccase, Pleurotus ostreatus, Purification, Properties, Microencapsulation

\section{Introduction}

Laccase (EC 1.10.3.2) is a blue copper protein, but it also falls within the broader description of polyphenol oxidases. Polyphenol oxidases are copper proteins with the common feature of being able to oxidize aromatic compounds with molecular oxygen as the terminal electron acceptor [1].

Laccases exists in 3 different classes as botanical, fungal and bacterial laccases. It is presented in numerous plants such as white-rot fungi. However, the fungal strains to be used should be properly inexpensive, sensitive and fast methods and screenings, and the productions of laccase should be their functions resistance and functional in the industrial field where they will be applied [2].
Their property could be to detoxify a range of pollutants. They have been used in many industries for several purposes. Application of laccase in food industry processing includes medical and health care. Recently, the design of biosensors and nanotechnology has been among the applications of laccase [3].

Currently, this enzyme is the central subject of many worldwide research groups, due to scientific curiosity and its high potential in numerous applications in biotechnology and bio-analytical chemistry. Laccases can oxidize a number of natural and synthetic substrates using oxygen, producing water as the only by-product and they have been used in a variety of industrial and environmental applications. Laccases which are able to oxidize recalcitrant compounds like lignin,

Corresponding author: olaseif20@yahoo.com

DOI: 10.21608/ajnsa.2019.3804.1090

(C) Scientific Information, Documentation and Publishing Office (SIDPO)-EAEA 
which makes them attractive for their uses in various biotechnological processes as is a versatile gas [4].

Reports have suggested that the use of free enzymes in traditional enzyme applications has many drawbacks which can be overcome by immobilization processes [5]. In some materials, the enzymes are encapsulated. This includes polymers, liposomes, and sol-gels or hydro-gels, depending on their sensing conditions. The enzymes are stabilized via encapsulation with new methods and materials, and their activity may be maintained for a longer time, and even the selectivity can possibly be enhanced. Compared to immobilization/entrapment techniques, microencapsulation has many advantages. The microcapsule is composed of a semi permeable, spherical, thin and strong membranous wall [6]. Moreover, compared to an entrapment matrix, there is no solid or gelled core in the microcapsule and its small diameter helps to reduce mass transfer limitations. The substrate can diffuse through the semi permeable membrane easily.

Due to their wide specificity, laccase is used in diverse biotechnological applications such as biobleaching, paper pulping, textile refining, dye decolorization, juice and wine clarification, organic synthesis, medical diagnostic tools and bioremediation of soil contaminated [5].

Laccases are important and promising enzymes for various industrial applications. However, their constitutive production from white rot fungi is very low. This greatly hinders their industrial exploitation. The present work aims at purification of laccase and studying its characters. A trial for immobilizing the enzyme by microencapsulation method have also been studied.

\section{Materials and Methodes \\ Organism}

Fungus Pleurotus ostreatus (ATCC 56270) was purchased from Microbiological Resources Centre (Cairo MIRCEN), Egypt (Al-Hagar et al., 2014). It was exposed to $0.5 \mathrm{KGy}$ Gamma irradiation and used in the present study.

\section{Medium}

Laccase production by the white rot fungus Pleurotus ostreatus ATCC 56270 has been investigated under solid state fermentation. The highest yield of laccase was recorded in case of using lignocellulosic waste (rice bran) with tap water in the presence of copper sulphate $0.005 \mathrm{~g} / \mathrm{l}$ as inducer according to AL-Hagar et al. [7]. The growth was allowed under the following optimum conditions: $30^{\circ} \mathrm{C}$; inoculums size of $2 \mathrm{ml}(6 \times 105$ spore $/ 2 \mathrm{ml}) ; \mathrm{pH} 4.5$ the enzyme was assayed according to Niku-Paavola et al. [8] using (2,2azino-bis-[3-ethyl-benzo-thiazolin-6 sulphonate]) ABTS.

\section{Purification of laccase from Pleurotus ostreatus \\ Laccase assay}

Laccase activity was determined by spectrophotometer Milton Roy spectronic 1201 as described by Niku-Paavola et al [8] using ABTS as a substrate. The total protein was estimated following the method of Lowry et al. [9] using bovine serum albumin as a standard protein.

Determination of the activation energy

Plots of the reaction rate vs temperature and the $\log$ of the rate (ln $\mathrm{k}$ ) vs $1 / \mathrm{T}$ were made to determine the activation energy. To determine the thermostability, the purified laccase was incubated at temperatures ranging from 30,40 and $60 \mathrm{oC}$ for various times (10-50 min). The residual activity was determined with ABTS as the substrate.

\section{Results}

Purification of laccase by ion exchange chromatography

The laccase enzyme was purified extracellularly from Pleurotus ostreatus in two steps, using chromatographic DEAE-Sepharose 6B and Sephacryl S-200 gel filtration chromatography Table (1). All purification procedures were performed at $25^{\circ} \mathrm{C}$. The laccase is purified from a cell-free culture medium $(250 \mathrm{ml})$ after being filtrated and centrifuged at a rate of $10,000 \mathrm{rpm}$ for $30 \mathrm{~min}$. The concentration of the filtrate is one tenth of the volume at $4^{\circ} \mathrm{C}$ with an Amicon ultrafiltration system which equipped with a filter type PTGC (pore size 10,000 normal molecular weight limit (NMWL). The centrifugations of solution at 10,000 rpm for 60 minutes and the supernatant was collected and exchange of extensive buffer was performed using stirred ultrafiltration cell (Amicon 8200, YM-30 membrane) with $0.01 \mathrm{M}$ acetate buffer $(\mathrm{pH}=6.0)$. The clarified cell extract $(25 \mathrm{ml})$ with specific activity $55.9 \mathrm{U} / \mathrm{mg}$ was loaded onto a DEAESepharose 6B column $(0.5 \times 10 \mathrm{~cm})$, pre-treated with polyvinyl alcohol $(1 \mathrm{~g} \%)$ and equilibrated in $0.01 \mathrm{M}$ acetate buffer $(\mathrm{pH}=6.0)$. At this step, specific activity increased to $202.3 \mathrm{U} / \mathrm{mg}$. The end 
step, the enzyme fractions obtained from the ion exchange column were concentrated and pooled and this sample was applied to the Sephacryl S200 column $(0.5 \times 10 \mathrm{~cm})$ equilibrated with 10 $\mathrm{mM}$ Tris- $\mathrm{HCl} 0.15 \mathrm{M} \mathrm{NaCl}(\mathrm{pH} 8)$. At this step, a single peak was obtained, and activity of the enzyme appeared in fractions (5-9) as shown in (fig.1) while fraction (7) gave a specific activity of $348.8 \mathrm{U} / \mathrm{mg}$. The bound protein was then eluted with the same buffer. Active fractions were stored at $-4^{\circ} \mathrm{C}$. At the end of the process, laccase was purified 6-fold.

\section{SDS Polyacrylamide gel electrophoresis}

Fraction 7 which gave the highest activity of laccase enzyme $(348.8 \mathrm{U} / \mathrm{mg})$, was subjected to SDS polyacrylamide gel electrophoresis as illustrated in Fig. (1).

The pure laccase produces one band on an SDSPAGE gel protein was about $75 \mathrm{kDa}$ as determined by SDS-PAGE Fig. (2).

\section{Effect of temperature on activity of the purified laccase and its stability}

The effect of temperature on the activity of the purified laccase was assayed in $50 \mathrm{M}$ sodium acetate buffer ( $\mathrm{pH} 4.5)$. The optimal temperature for the enzyme activity was $35 \mathrm{oC}$ as shown in Fig. (3).

During the examination of thermal stability, the enzyme must be incubated for one hour at temperatures $20,35,40$, and $60 \mathrm{oC}$. The purified enzyme retained $70 \%$ at $35 \mathrm{o} \mathrm{C}$ of its beginning activity after 1h Fig. (4).

Temperature effect on enzyme activity of enzyme was assayed in $50 \mathrm{mM}$ of sodium acetate buffer (pH 4.5)

\section{Determination of the energy activation}

The activation energy (Eact) of the purified laccase between $20^{\circ} \mathrm{C}$ and $55^{\circ} \mathrm{C}$ at its optimum pH $(\mathrm{pH}=$ 4.5) was $16.3 \mathrm{kJmol}-1$ as shown in Fig. (5). This is higher than $3.9 \mathrm{kJmol}-1$ of Pleurotus florida laccase [10] and $12 \mathrm{kJmol}-1$ of P. sajor-caju laccase [11].

\section{The pH effect on activity of the purified laccase and its stability}

The $\mathrm{pH}$ effect on laccase activity and its stability using ABTS as a substrate was studied; the activity of laccase was investigated in the $\mathrm{pH}$ range of 3.78. The optimal $\mathrm{PH}$ of the enzyme was determined to be 5 and it became less active at level of $\mathrm{pH} 7$ and 8 as shown in Fig. (6).

Effect of $\mathrm{pH}$ on the laccase was measured in $0.1 \mathrm{M}$ sodium acetate buffer $(\mathrm{pH} \mathrm{3.7,} \mathrm{4,} \mathrm{4.6,} 5$ and 5.5) and $0.1 \mathrm{M}$ phosphate citrate buffer $(\mathrm{pH} 6,6.5,7$ and 8). To analyze the $\mathrm{pH}$ stability, the purified laccase was incubated at $25^{\circ} \mathrm{C}$ for $1 / 2 \mathrm{~h}$ at the previous $\mathrm{pH}$ range.

A study of the enzyme stability showed that the enzyme at $\mathrm{PH}$ value above 7 was unstable, but the purified laccase was very stable at $\mathrm{pH}$ values from 3.7 to 5 . Laccase retained $99 \%$ of its initial activity after $1 / 2 \mathrm{~h}$ at $\mathrm{pH} 4.6$ Fig. (6), and $97.8 \%, 96.7 \%$, $94.3 \%$ of its retained initial activity after $1 / 2 \mathrm{~h}$ at $\mathrm{pH} 3.7,4,5$ respectively. At $\mathrm{pH} 7,8$ laccase was less active as it retained only $34 \%$ and $20 \%$ of its initial activity respectively.

\section{Kinetic parameters of the Purified Laccase}

As shown in Fig. (7) relation between substrate concentration ABTS and enzyme activity $(\mu \mathrm{M})$ and $\Delta$ absorbance min-1. Activity was measured at different ABTS concentrations (100, 200, 300, $400,500,600,700$ and $800 \mu \mathrm{M})$ in $50 \mathrm{mM}$ of sodium acetate buffer $(\mathrm{pH} 5)$ at $350 \mathrm{C}$.

The data in Table (3) summarized kinetic parameters of the purified laccase enzyme

Table (1): Steps in purifying to homogeneity the laccase enzyme detected in the supernatant of Pleurotus ostreatus ATCC56270

\begin{tabular}{|l|c|c|c|c|c|c|}
\hline \multicolumn{1}{|c|}{$\begin{array}{c}\text { Purification } \\
\text { Step }\end{array}$} & $\begin{array}{c}\text { Total } \\
\text { volume } \\
(\mathrm{ml})\end{array}$ & $\begin{array}{c}\text { Enzyme } \\
\text { Activity } \\
(\mathrm{U} / \mathrm{ml})\end{array}$ & $\begin{array}{c}\text { Total } \\
\text { Activity } \\
\text { (Units) }\end{array}$ & $\begin{array}{c}\text { Protein } \\
(\mathrm{mg})\end{array}$ & $\begin{array}{c}\text { Specific } \\
\text { Activity } \\
(\mathrm{U} / \mathrm{mg})\end{array}$ & $\begin{array}{c}\text { Purification } \\
\text { Fold }\end{array}$ \\
\hline Crude extract & 250 & 28.57 & 7142.5 & 127.8 & 55.9 & 1 \\
\hline DEAE-sepharose & 25 & 83.33 & 2083.25 & 10.3 & 202.3 & 3.62 \\
\hline Sephacryl-HR & 5 & 30.0 & 150.0 & 0.43 & 348.8 & 6.24 \\
\hline
\end{tabular}

Arab J. Nucl. Sci. \& Applic. Vol. 52, No. 2 (2019) 


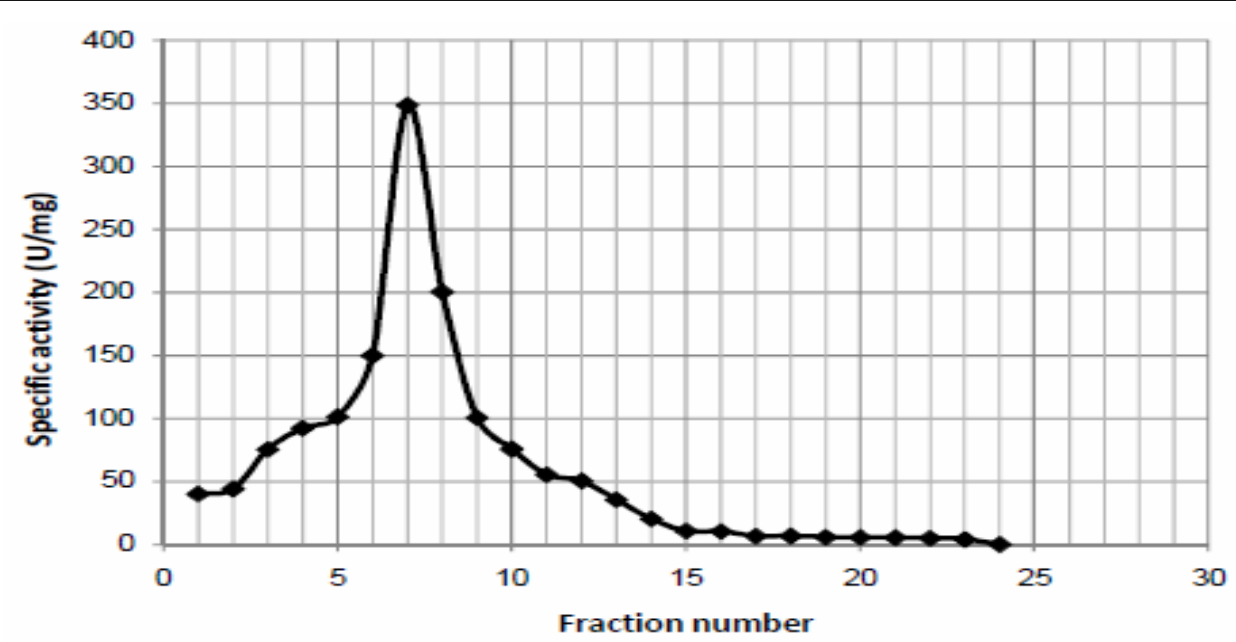

Fig. (1): Active fractions of purified laccase from Pleurotus ostreatus ATCC 56270

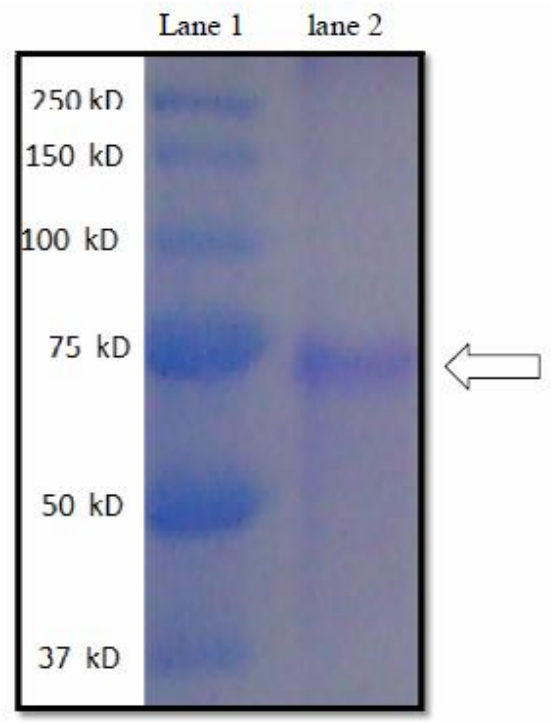

Fig. (2): SDS polyacrylamide gel electrophoresis of standard proteins (Bangalore Genei) (lane 1), purified laccase from

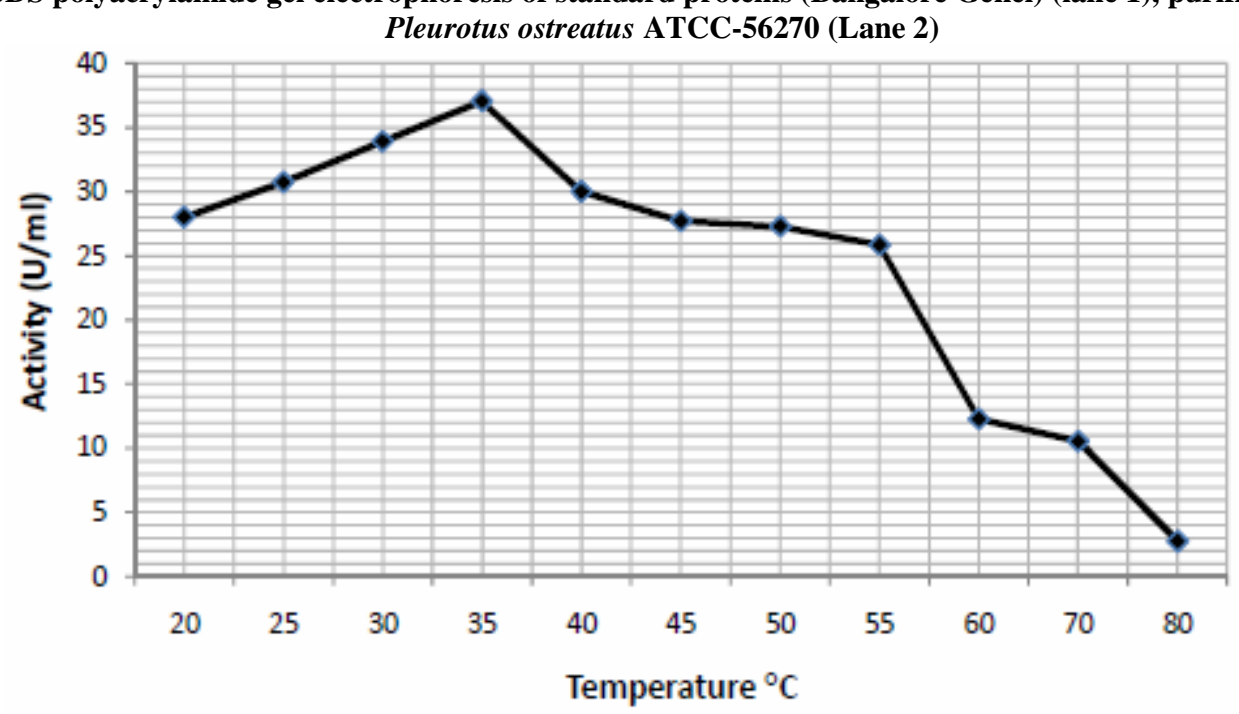

Fig. (3): temperature effect on activity of purified laccase of Pleurotus ostreatus ATCC 56270 


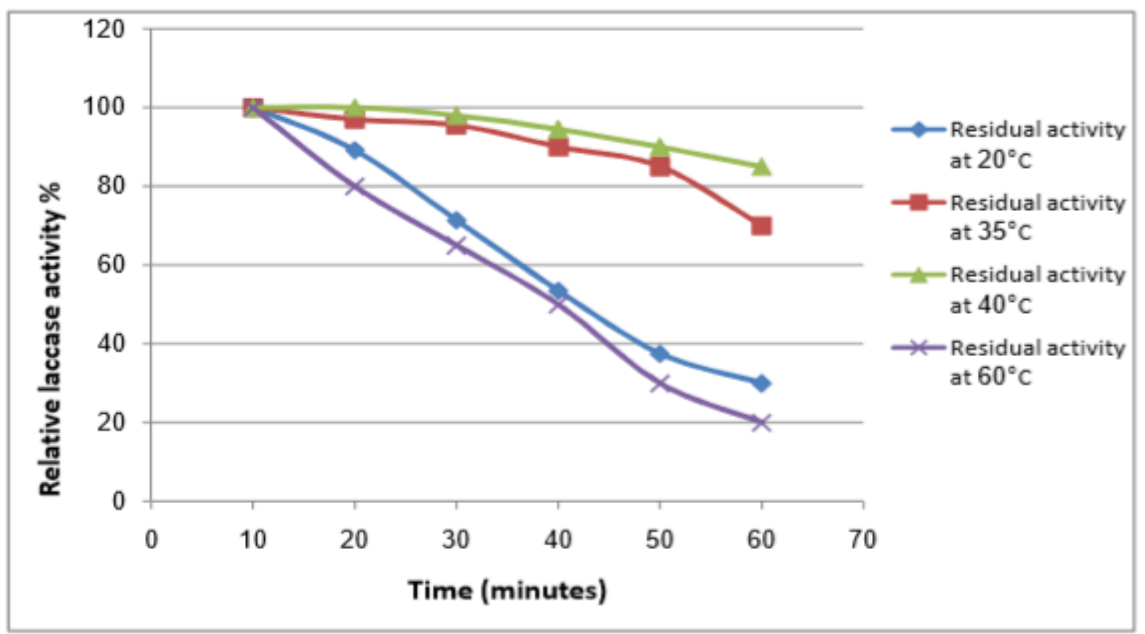

Fig. (4): Thermal stability of laccase purified of pleurotus ostreatus ATCC 56270 represented as \% relative activity vs temperature after $1 \mathrm{~h}$ incubation at the indicated temperatures

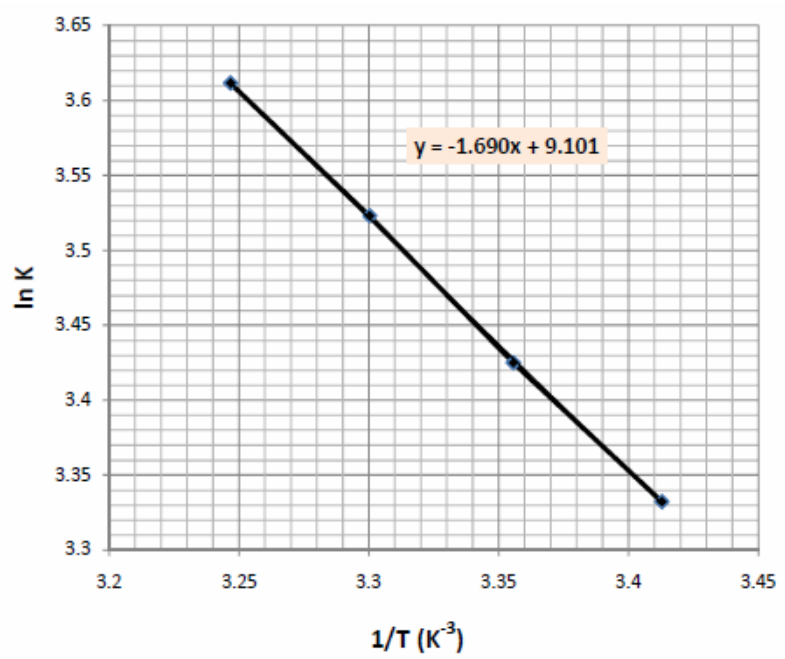

Fig. (5): Plots of the log of the reaction rate vs (1/T kalvin) were made to determine the energy of activation

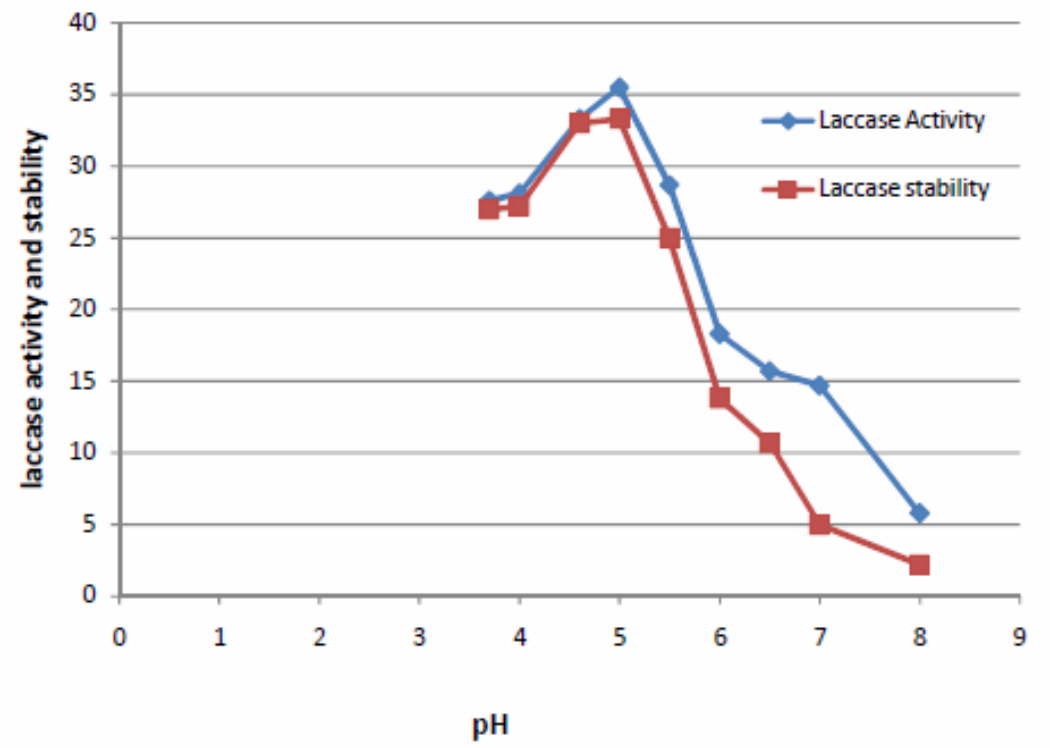

Fig. (6): Effect of The PH effect the stability and activity of the purified laccase of pleurotus ostreatus ATCC 56270 


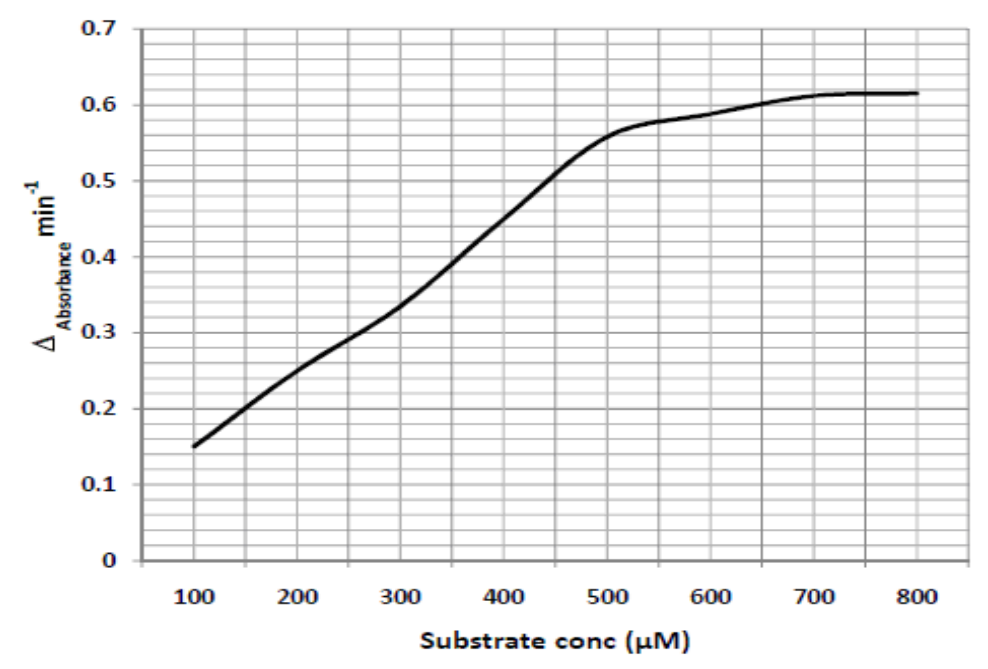

Fig. (7): Relation between substrate concentration $(\mu M)$ and $\Delta_{\text {absorbance }} \min ^{-1}$. Activity

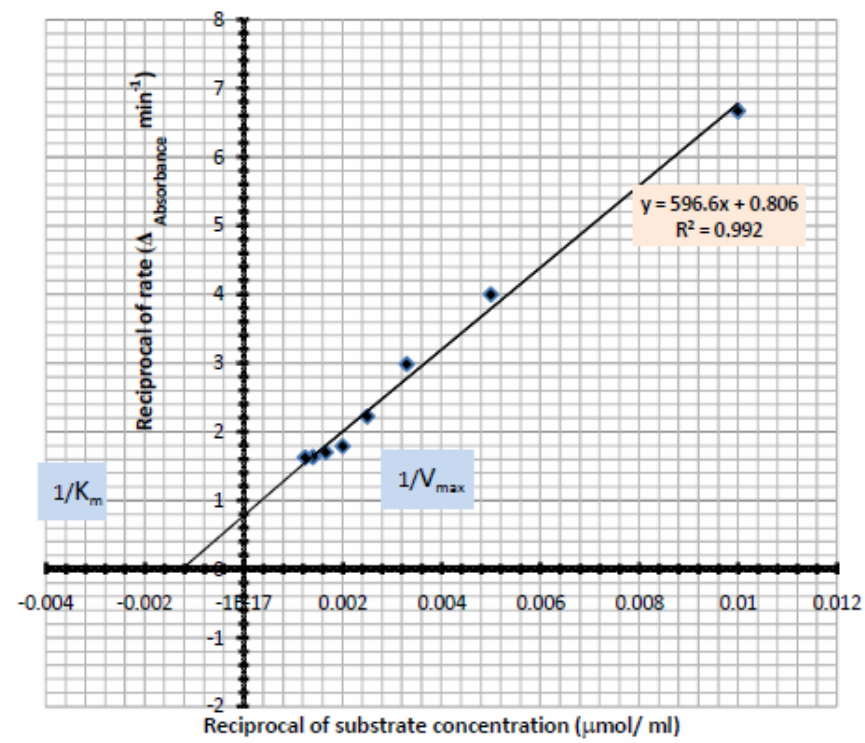

Fig. (8): Lineweaver-Burk double reciprocal plot of reaction rate $\left(\Delta_{\text {absorbance }} \min ^{-1}\right)$ versus the reciprocal of substrate concentration for the purified laccase

Table (2): Kinetic parameters of the purified laccase

\begin{tabular}{|c|c|c|c|c|}
\hline Substrate & $\begin{array}{c}K m \\
(\mathrm{mMol} / \mathrm{l})\end{array}$ & $\begin{array}{c}\operatorname{Vmax} \\
\left(\mu \mathrm{mol} \mathrm{L} \mathrm{min}^{-1}\right)\end{array}$ & $\begin{array}{c}K_{\text {cat }} \\
\left(\mathrm{min}^{-1}\right)\end{array}$ & $\begin{array}{c}K_{\text {ca- }} / \mathrm{Km} \\
\left(\mathrm{min}^{-1} \mu \mathrm{M}^{-1}\right)\end{array}$ \\
\hline ABTS & 1.4 & 1.2 & 3450 & 2464 \\
\hline
\end{tabular}




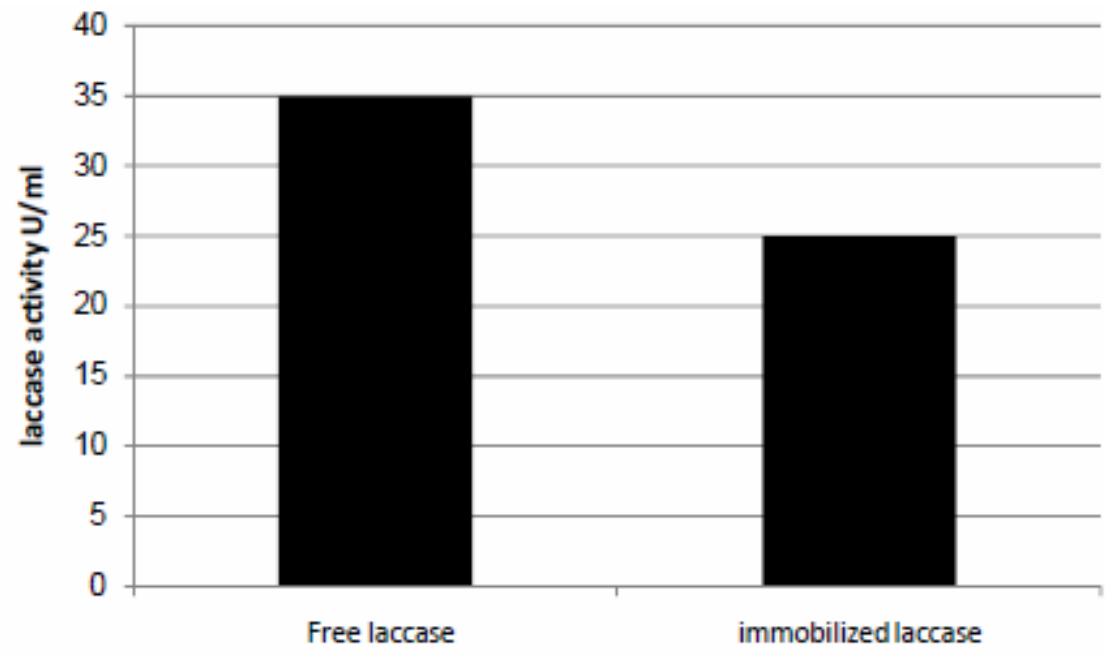

Fig. (9): laccase activity of the free and the immobilized enzyme on alginate

\section{Encapsulation of the purified laccase}

A natural polymer as alginate can easily be converted into hydrogels via divalent cations cross-linking. Encapsulation of laccase and Alcohol dehydrogenase in alginate beads was studied according to Wang et al. [12]. The immobilized laccase beads $(2-3 \mathrm{~mm})$ were formed by entrapping the enzyme in alginate beads, laccase From S. psammoticus partially purified laccase was immobilized by entrapment physically in alginate beads.

The activities of the free and the immobilized laccase were assayed at temperatures $30^{\circ} \mathrm{C}$ in a thermostatically controlled water bath under the standard assay conditions. The results were depicted in Fig. (9) which shows that free laccase $(35 \mathrm{U} / \mathrm{ml})$ has a higher activity than the encapsulated laccase $(24.3 \mathrm{U} / \mathrm{ml})$.

\section{DISCUSSION}

In the present study, the laccase enzyme produced by Pleurotus ostreatus ATCC 56270 was subjected for purification steps. The cell free filtrate was concentrated using Amicon Ultra filtration system giving $55.9 \mathrm{U} / \mathrm{mg}$ activity, then loaded on DEAEsepharose 6B column pretreated with polyvinyl alcohol $(1 \mathrm{~g} \%)$ and equilibrated in $0.01 \mathrm{M}$ acetate buffer $(\mathrm{pH}=6.0)$ to increase the activity up to 202.3 U/mg with 3.62 purification fold. Then a second column of Sephacry S-200 column $(0.5 \mathrm{x}$ $10 \mathrm{~cm}$ ) was equilibrated with $10 \mathrm{mM}$ Tris- $\mathrm{HCl}$,
$0.15 \mathrm{M} \mathrm{NaCl}(\mathrm{pH} 8)$ to obtain a single peak with specific activity $348.8 \mathrm{U} / \mathrm{mg}$ for fraction (7) with purification fold 6.24. Findings of other investigators have shown that the production of crude extracellular laccase by Anoxybacillus gonensis P39 using DEAE-celulose ion and the laccase was purified utilizing exchange chromatography and Sephacryl S200 gel filtration chromatography techniques resulting in 4.16, 11.69, and 83.4 purification folds [13]. The purified laccase gave one band on SDS-PAGE gel protein with $75 \mathrm{KDa}$ [14]. The purified laccase from Melanocarpus albomyces gave $80 \mathrm{kDa}$ [15].

As for the effect of temperature on the purified laccase produced by Pleurotus ostreatus ATCC 56270 , the optimal temperature was found to be $35 \mathrm{oC}$, while Wang and Hsu [16] reported the optimal temperature to be $30 \mathrm{oC}$ by endophytic fungus Monotospora sp. and Irshad et al. [17] reported it as $40 \mathrm{oC}$ from schysophylum commune IBL-60. Laccase Low thermostability was observed as it retained only $20 \%$ of its initial activity after $1 \mathrm{~h}$ incubation. Thermal stability varied with different temperatures, this depends on microorganisms sources. For example, after $1 \mathrm{~h}$ incubation at 55oC [15], the laccase from $\mathrm{T}$. harzianum retained $70 \%$ of its starting activity, whereas the laccase produced from Daedalea quercina was more stable below this temperature. Laccase was most stable at $40 \mathrm{oC}$ as it retained $100 \%$ of its activity after 20 minutes incubation, 
$85 \%$ of its activity after $1 \mathrm{~h}$ incubation at the same temperature. At $60 \mathrm{oC}$ laccase was less stable as it retained only $20 \%$ of its initial activity after $1 \mathrm{~h}$ incubation. However, the activity decreased at higher temperatures [18-19].

The activation energy (Eact) of the purified laccase between $20^{\circ} \mathrm{C}$ and $45^{\circ} \mathrm{C}$ at its optimum $\mathrm{pH}(\mathrm{pH}=$ 4.5) was $16.3 \mathrm{kJmol}-1$ as shown in Fig. (18). This is higher than $3.9 \mathrm{kJmol}-1$ as reported by Pleurotus florida laccase [10] and $12 \mathrm{kJmol}-1$ as reported by P. sajor-caju laccase [11]. On the other hand, it is lower than $60 \mathrm{kJmol}-1$ of Coriolus versicolor (19). The effect of the $\mathrm{pH}$ and $\mathrm{pH}$ stability on the laccases which were produced from $\mathrm{C}$. hirsutus, $\mathrm{T}$. atroviride, and Chalara (syn. Thielaviopsis) paradoxa $\mathrm{CH} 32$ was optimal at $\mathrm{pH}$ range of 4-6 [15]. The activity of many laccases decreases rapidly beyond the optimum $\mathrm{pH}$ [20-22], but this laccase showed a high relative activity over a broad $\mathrm{pH}$ range from 3.7 to 5 . This could be a very useful characteristic for various industrial applications. Various substrates with a decrease in oxidation rate was observed at a higher $\mathrm{pH}$, which may be due to ionization of critical amino acids (Asp and Glu), this indicates that the enzyme was inactive at a higher $\mathrm{pH}$ [23].

To improve the catalytic properties of laccase, such as the high affinity for its substrate and relatively high turnover numbers, especially for the oxidation of ABTS, this enzyme that proved to be highly competitive for this industrial application was used. The apparent $\mathrm{Km}$ value of the enzyme for ABTS as determined from the Line weaverBurk plot Fig. (6) was estimated to be $1.4 \mathrm{mM}$ under standard assay conditions. $\mathrm{V}$ max is the maximum begging rate in the Michaelis-Menten equation $(1.2 \mu \mathrm{mol} \mathrm{L}-1 \mathrm{~min}-1)$. The kcat value for ABTS, 3450 min -1, was higher than that of the laccase of C. subvermispora which was $101 \mathrm{~s}-120$, T. villosa (2700 s-1), P. cinnabarinus (920 s-1), Myceliophthora thermophila (440 s-1), and Botrytis cinerea that was $23 \mathrm{~s}-1$ [24]. The previous result suggested that the ABTS might be an effective mediator of this enzyme. For the laccase mediator to be effective the laccase structure should be modified by increasing its kcat so as to improve its stability against free radical attack.

Laccase was immobilized by entrapment into alginate. After entrapping of the enzyme, the immobilized laccase beads $(2-3 \mathrm{~mm})$ were formed. In the present study, the preparation of calcium alginate and copper alginate beads from two different cations such as calcium and copper respectively. Calcium alginate is the most commonly used for enzyme immobilization support while copper alginate gels are used for laccases specifically [25]. There is a different parameter where the formation and the mechanical and structural properties of alginate beads depend on the alginate concentration, and concentration of the cations and nature of the cations [26].

\section{Conclusion}

The process of laccase purification has been successfully performed by anion exchange chromatography using DEAE sepharose and sephacryl HR. The molecular weight of laccase was $75 \mathrm{KDa}$ determined by SDS- PAGE. The optimum $\mathrm{pH}$ value for the activity was 5 , and for the stability was 6.5-7.5, the optimum temperature for the activity was $35 \mathrm{oC}$ and the stability of the enzyme was $40 \circ \mathrm{o}$. The enzyme retained $100 \%$ of its activity after 20 minutes incubation, $85 \%$ of its activity after $1 \mathrm{~h}$ incubation at the same temperature. The free laccase $(35 \mathrm{U} / \mathrm{ml})$ has a higher activity than encapsulated laccase (24.3 $\mathrm{U} / \mathrm{mi})$.

\section{References}

1. Mayer A.M. (1987): Polyphenol oxidases in plants - recent progress.Phytochemistry, 26: 11-20.

2. Yanmis D., Adiguzel A., Nadaroglu H, Gulluce M., Demir N. (2016): Purification and Characterization of Laccase from Thermophilic Anoxybacillus Gonensis P39 and its application of removal textile dyes. Romanian Biotechnological Letters, Vol. 21, No. 3.

3. Pooja upadhyay, Rahul Shrivastava and Pavan Kumar Agrawal. (2016): Bioprospecting and biotechnological application of fungal laccase. 3 Biotech, 6: 15.

4. Kim J., Jia H. and Wang P. (2006): Challenges in biocatalysis for enzyme-based biofuel cells. Biotechnology Advances, 24: 296 - 308.

5. Bagewadi Z.K., Mulla S.I., Ninnekar H.Z. (2017): Purification and immobilization of laccase from Trichoderma harzianum strain HZN10 and its application in dye decolorization. Journal of Genetic Engineering and Biotechnology, 15: 139-150.

6. Jankowski T., ZXielinska M. and Wysakowska A. (2006): Encapsulation of lactic acid bacteria with alginate/starch capsules. Biotechnol.tech, 11:31-34. 
7. Al-Hagar O.E.A., Abdel-Aziz A.F., Atia K.S and Mansour H.A. (2014): Enhancement of laccase production by Pleurotus ostreatus under solid state fermentation. Isotope \& Rad. Res., 46(2), 221-237.

8. Niku-Paavola M. L., Raaska L. and Itavaara M. (1990): Detection of white rot fungi by a non- toxic stain. Mycology Research, (94): $27-$ 31.

9. Lowry O.H., Rosebrough N.J., Farr A.L. and Randall R.J. (1951): Protein measurement with the folin phenol reagent. J. Biol. Chem. 193:265-275.

10. Das N., Chakraborty T.K. and Mukherjee M. (2001): Purification and characterization of Growth-regulating laccase from Pleurotus florida. J. Basic Microbiol, 41: 261-267.

11. Lo A.S.C., Ho Y.S. and Buswell J.A. (2001): Effect of phenolic monomers on the production of laccases by the edible mushroom Pleurotus sajor-caju and partial characterization of a major laccase component. Mycologia, 93, 413421.

12. Wang P., Hu X., Cook S., Begonia M., Lee K.S. and Hwang H.M. (2008): Effect of culture conditions on the production of ligninolytic enzymes by white rot fungi Phanerochaete chrysosporium (ATCC 20696) and separation of its lignin peroxidases, W. J. Microbiol. Biotechnol, 5-31.

13. Derya Yanmis, Ahmet Adiguzel, Hayrunnisa Nadaroglu, Medine Gulluce and Nazan Demir (2016): Purification and characterization of laccase from thermophilic Anoxybacillus Gonensis P39 and its application of removal textile dyes. Romanian Bactechnological Letters, Vol. 21, No.3.

14. Kiiskinen L. L., Kruus K., Bailey M., Ylösmäki E., Siika-aho M. and Saloheimo M. (2004): Expression of Melanocarpus albomyces laccase in Trichoderma reesei and characterization of the purified enzyme.Microbiology 150:3065-3074.

15. Sadhasivam S., Savitha S., Swaminathan K. and Lin F.H (2008): Production, purification and characterization of mid-redox potential laccase from a newly isolated Trichoderma harzianum WL1. Process biochem, 43: 736742.

16. Wang H.T. and Hsu J.T. (2006): Usage of enzyme substrate to protect the activities of cellulase, protease and $\alpha$-amylase in simulations of monogastric animal and avian sequential total tract digestion. Asianaustralasian journal of animal sciences, 19: 1164-1173.

17. Irshad M., Asgher M., Shiekh M. A. and Nawaz H. (2011): laccase from banana stalks. Bioresources, 6(3):2861-2873.

18. Baldrian P. (2004): Purification and characterization of laccase from the white-rot fungus Daedalea quercina and decolorization of synthetic dyes by the enzyme.J. Appl. Microbiol. Biotechnol, 63: 560-56318.

19. Zhang L.H., Li D., Wang L.J., Wang T.P., Zhang L., Chen X.D. and Mao Z.H. (2008): Effect of steam explosion on biodegradation of lignin in wheat straw. Bioresource Technol, 99: 8512-8515.

20. Min K.L., Kim Y.H., Kim Y.W., Jung H.S. and Hah Y.C. (2001): Characterization of a novel laccase produced by the wood-rotting fungus Phellinus ribis. Arch. Biochem. Biophys, 392: 279-286.

21. Jung H., Xu F. and Li K. (2002): Purification and characterization of laccase from wooddegrading fungus Trichophyton rubrum LKY7. Enzyme Microb. Technol, 30: 161-168.

22. Iyer G. and Chattoo B.B. (2003): Purification and characterization of laccase from the rice blast fungus, Magnaporthe grisea. FEMS Microbiol Lett, (227): 121-126.

23. Salony S., Mishra V., and Bisaria S. (2006): Production and characterization of laccase from Cyathus bulleri and its use in decolourisation of recalcitrant textile dyes. Appl Microbiol Biotechnol, 71:646-653.

24. Shin K.S. and Lee Y.J. (2000): Purification and characterization of a new membar of the laccase family from the white-rot basidiomycete Coriolus hirsutus. Arch Biochem Biophys, 384: 109-115.

25. Palmieri G., Giardina P., Bianco C., Scaloni A., Capasso A. and Sannia G. (1997): A Novel White Laccase from Pleurotus ostreatus. J Biol Chem 272:31301-31307.

26. Ouwerx C., Vellings N., Mestdagh M.M. and axelos M.A.V. (I998): physicochemical properities and rheology of alginate gel beads formed with various divalent cations.polym gels network, 6:393-408 